\title{
Optimization of total RNA extraction protocol from Ziarat Juniper (Juniperus excelsa M.Bieb)
}

\author{
Humaira Abdul Wahid*, Muhammad Younas Khan Barozai, \\ Muhammad Din \\ Department of Botany, University of Balochistan, Sariab Road Quetta, Pakistan \\ *Corresponding author email: humairawhaid@yahoo.com
}

\section{Citation}

Humaira Abdul Wahid, Muhammad Younas Khan Barozai, Muhammad Din. Optimization of total RNA extraction protocol from Ziarat Juniper (Juniperus excelsa M.Bieb). Pure and Applied Biology. Vol. 4, Issue 2, 2015, pp 15-23

\begin{tabular}{lcc}
\hline \hline Received: 11/02/2015 & Revised: 10/04/2015 & Accepted: 12/04/2015 \\
\hline \hline
\end{tabular}

\section{Abstract}

Ziarat Juniper (Juniperus excelsa) forest, in Balochistan Province, has importance because of the second largest Juniper forest in the world and one of the oldest slow growing Juniper trees of the world having trees as old as 2500 to 3500 years. Total RNA extraction from Ziarat Juniper will be the entrance of transcriptome world to reveal functional genome of this important plant (Juniperus excelsa). But its high phenolic compounds and polysaccharides contents cause rapidly bind or co-precipitate with RNA during RNA extraction. So standard protocols for RNA extraction do not produce high quality total RNA. In this study, an optimized total RNA extraction protocol based on used of CTAB (Cetyl Trimethyl Ammonium Bromide) PVP (Polyvinyl Pyrrolidone) and 2-mercaptoethanol, in the extraction buffer and an extraction with organic solvents (Phenol and Chloroform) is described for Juniperus excelsa shoot. Agarose gel electrophoresis clearly showed $28 \mathrm{~S}$ and $18 \mathrm{~S}$ ribosomal RNA bands and produced RNA with high yield (1.5-2.0 $\mu \mathrm{g} / \mu \mathrm{l})$ and high quality (1.9-2.0 A260/280 ratio). Thus this protocol for RNA extraction is suitable for molecular analysis of Juniperus excelsa.

Keywords: Juniperus excelsa; Phenolic compounds; RNA extraction

\section{Introduction}

Junipers are coniferous plants in the genus Juniperus of the family Cupressaceae [1]. The genus Juniperus comprises about 70 species [2] which occur throughout the northern hemisphere of the world [3]. Shrubs and trees in this genus are slow growing [4] and can live more than 1,500 years [5]. Junipers produce a variety of wood and non-wood forest products of value to human societies $[6,7]$.

In Pakistan Juniper forests of Balochistan is our national and biological heritage [8] and considered as one of the world's largest, oldest, drought resistant tree species [9]. Balochistan has approximately 141,000 hectors of Juniperus excelsa forests, out of which approximately 86,000 hectors of these are found in Ziarat and Loralai districts. The 
Ziarat Juniper is dry temperate Juniper forest [10] with evergreen Juniper excelsa as dominant species.

Higher trees are rich in secondary metabolites, polysaccharides and polyphenolics. Juniperus like many higher plant species, contain abundant polyphenolic and polysaccharide compounds. Daniel and justyna [11] reported $2.40 \pm 0.23 \%$ to $3.43 \pm 0.17 \%$ phenolic compounds in sprouts of Juniperus communis L. and Reza et al., [12] reported $1.85 \pm 0.02 \mathrm{mg} / \mathrm{g} \pm \mathrm{SD}$ phenolic compounds in crude extract of Juniperus excelsa fruit.

The isolation of high-quality total RNA is necessary for downstream molecular research. The isolation of total RNA from many plants specially the higher plants is very difficult because they contain high quantities of metabolites, e.g., phenolics and polysaccharides that bind with RNA during extraction. Several studies describe extraction techniques for specific plant tissues that creates problems for the isolation of high-quality RNA [13-20]. Some RNA extraction protocols for plants rich in phenolics and polysaccharides use sodium dodecyl sulfate (SDS), soluble polyvinyl pyrrolidone (PVP) and ethanol precipitation [21] Chomczynski and Sacchi [22] modified an acid guanidinium thiocyanate-phenolchloroform method and Wan and Wilkins [23] modified the hot borate method. One modified protocol used acetone treatment of freeze-dried and powdered plant materials [24] and another modified the cetyl trimethyl ammonium bromide (CTAB) method [25, 26].

In this study modified protocol to isolate high yield and purified total RNA from Juniperus excelsa is described which is suitable for further downstream molecular research.

\section{Materials and Methods Sample collection}

Samples (Shoots) of Juniperus excelsa were collected from Sasnamana Valley, Ziarat, Balochistan. The collected samples were stored in air sealed polythene bags.

\section{Reagents and solutions}

An extraction buffer consisting of 3\% CTAB (w/v), $\mathrm{NaCl}(2 \mathrm{M}), 100 \mathrm{mM}$ Tris$\mathrm{HCl} \mathrm{pH} 8.0$ and $25 \mathrm{mM}$ EDTA pH 8.0 was prepared. After being autoclaved for $20 \mathrm{~min}$, $3 \%$ PVP (w/v), 2\% (v/v) 2-mercaptoethanol and $2 \% \operatorname{SDS}(\mathrm{w} / \mathrm{v})$ were added to the extraction buffer. In addition, acidic Phenol: chloroform: isoamyl alcohol (25:24:1, $\mathrm{v} / \mathrm{v} / \mathrm{v})$, chloroform: isoamyl alcohol (24:1, v/v), Ethanol $(70 \%, 100 \%)$, Sodium acetate $(5 \mathrm{M})$ solution ( $\mathrm{pH} 8.0)$, DEPC and TAE buffer were the additional solutions used in this optimization protocol.

\section{Total RNA extraction}

Glass material and mortar \& pestle were treated with $0.1 \%$ DEPC-treated water and autoclaved. RNA was extracted by following method.

Almost $100 \mathrm{mg}$ frozen tissue per sample was ground in $1 \mathrm{ml}$ extraction buffer $(3 \%$ CTAB (w/v), $\mathrm{NaCl}(2 \mathrm{M}), 100 \mathrm{mM}$ Tris- $\mathrm{HCl} \mathrm{pH}$ 8.0, 25mM EDTA pH 8.0, 3\% PVP (w/v), $2 \%(\mathrm{v} / \mathrm{v})$ 2-mercaptoethanol and 2\% SDS $(\mathrm{w} / \mathrm{v})$. The mixture was vigorously mixed and incubated at room temperature for 10 min with 2-3 times vortex and centrifuged for $15 \mathrm{~min}$ at $13,000 \mathrm{rpm}$ at $4^{\circ} \mathrm{C}$. The supernatant was transferred to a new $1.5 \mathrm{ml}$ Eppendorf tube and extracted with equal volume of chloroform: isoamyl alcohol $(24: 1, \quad \mathrm{v} / \mathrm{v})$ thoroughly mixed and centrifuged for $15 \mathrm{~min}$ at $13,000 \mathrm{rpm}$ at $4^{\circ} \mathrm{C}$. The supernatant was again transferred to a new tube and equal volume of acidic phenol/chloroform/isoamyl alcohol (PCI) $(25: 24: 1, \quad \mathrm{v} / \mathrm{v} / \mathrm{v})$ was added mixed thoroughly and Centrifuge at 13000rpm for $20 \mathrm{~min}$ at $4^{\circ} \mathrm{C}$. The upper aqueous phase was transferred to a new tube. RNA was 
precipitated with $20 \mathrm{ul}$ of $5 \mathrm{M}$ sodium acetate and twice volume of $100 \%$ ethanol and the mixture was left overnight at $-20^{\circ} \mathrm{C}$. After overnight incubation at $-20^{\circ} \mathrm{C}$, RNA was collected by centrifugation at $13,000 \mathrm{rpm}$ for $20 \mathrm{~min}$ at $4^{\circ} \mathrm{C}$. The pellet was washed with $70 \%$ ethanol by centrifuging at $13,000 \mathrm{rpm}$ for $10 \mathrm{~min}$ at $4^{\circ} \mathrm{C}$. Ethanol was discard and pellet was allow to air dry. After air drying the RNA was dissolved in 80ul DEPC treated water and stored at $-20^{\circ} \mathrm{C}$.

Quantitative and Qualitative analysis

Quantitative analysis of RNA was performed by measuring optical density at $260 \mathrm{~nm}$ and $280 \mathrm{~nm}$ using Genova Nano spectrophotometer. Polysaccharide contamination was determined by maximum absorbance measurement at $230 \mathrm{~nm}$. Ratio measurements at wavelengths 230, 260 and 280 indicated degree of RNA purity. The absorption ratio A260/230 indicated polysaccharide/polyphenolic contaminants and A260/280 indicated protein contaminates $[25,26]$. Total RNA were loaded on a $1 \%$ agarose gel, stained with ethidium bromide (EtBr) [27] electrophoresed to separate RNA, and visualized under UV light to assess the integrity of ribosomal bands.

\section{Results and Discussion}

In this study a modified method was applied to the isolation of RNA from Juniperus excelsa containing high amounts of polysaccharides and phenolic compounds. Similar study was done by Chun et al., [28] in fruit trees and Evi et al., [29] in different plant tissues that contain large amounts of polysaccharides and polyphenol compounds. Lee, et al [30] developed an optimized RNA isolation protocol for peach fruits based on several protocols developed for isolating RNA from grape berries, pine trees, and woody plants Cinnamomum tenuipilum [3133]. The isolated RNA was of high quality as it showed a reading in between 1.8 to 2.1 after calculating the ratio of absorbance 260/280 nm.

The ethidium bromide fluorescence of the two ribosomal RNAs (28S and 18S) indicated that the RNA was not degraded and was of good quality (Fig. 1). This modified protocol made it possible to extract high quality RNA from Juniperus excelsa, which can be used in future molecular characterization and further downstream applications.-

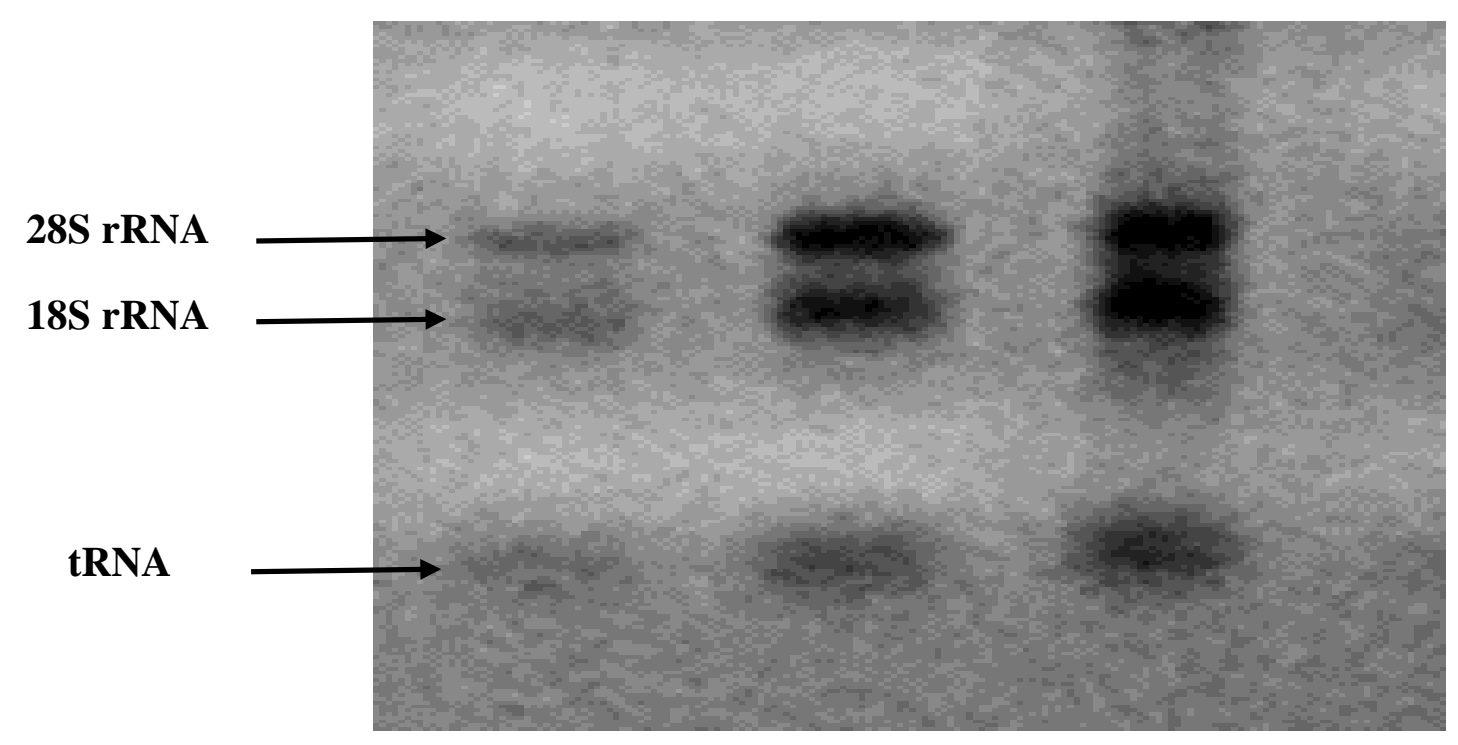

Figure-1 Total RNA was extracted from the shoots of Juniper tree (Juniperus excelsa) and run on $1 \%$ agarose gel, stained with ethidiußz bromide, showing two intact rRNA bands 


\section{Acknowledgments}

This paper is a part of the research project (HEC-NRPU Project 20-1867/R\&D/11) financed by the higher education commission (HEC) of Pakistan, Islamabad. The authors highly thankful and acknowledged this financial support of the higher education commission (HEC) of Pakistan, Islamabad.

\section{References}

1 Farjon A (1992). The Taxonomy of multiseed Junipers (Juniperus Sabina) in southwest Asia and East Africa. E. J. Bot., 49(3): 251-283.

2. Gulacti T, Ramazan E, Osman C, Candan J, Cennet C, Chai HB \& Pezzuto JM (1999). Diterpenes from the berries of Juniperus excelsa. Phytochem. 50(7): 1195-119.

3. Farjon A (1998).World Checklist and Bibliography of Conifers, Royal Botanic Gardens Kew.

4. Unlu M, Vardar-Unlu G, Vural N, Donmez E, \& Cakmak O (2008). Composition and antimicrobial activity of Juniperus excelsa essential oil Chemistry of Natural Compounds. 44 (1) 129-131.

5. Frenzel B, Jian L \& Shijian L (1995). On the upper quaternary paleoecology of eastern Tibet-preliminary results of an expedition to the eastern tibetan plateau. sci. Chin., 38(4): 485-94.

6. Lawson E (1990). Juniperus virginiana L. eastern redcedar. Silvics of North America. Conifers. Agric. Handb. 654. Washington, D.C. U.S. Dept. of Agric., Forest Service, 1: 131-140.

7. Ciesla WM (1998). Non-wood forest products from conifers. Non- wood forest products 12. FAO, United Nations, Rome, 124 pp. 992.

8. Sarangzai AM (2004). Occurrence of juniper Dwarf Mistletoe, Arceuthobium oxycedri (DC.) M. Bieb. in Balochistan province, Pakistan. Pak. J. Weed Sci. Res., 10(1-2): 73-78.
9. Sheikh IS (1985). Afforestation in Juniper forests of Balochistan. Pakistan Forest Institute, Peshawar.

10. Muhammad A, Hussain T, Shaikh AH, Hussain SS \& Siddiqui MF (2006). Phytosociology and structure of Himalayan forests from different climatic zones of Pakistan. Pak. J. Bot., 38(2): 361-383.

11. Daniel M \& Justyna L (2009). Estimation of the total phenolic compounds in juniper sprouts (Juniperus communis L., Cupressaceae) from different places at the kujawsko-pomorskie province. Herba polonica, 55 (3) 127-132.

12. Wahid HA, Barozai MYK, Din $M$ (2015). Dwarf mistletoe (Arceuthobium oxycedri) and damage caused by dwarf mistletoe to family Cupressaceae. Pure and Applied Biology. 4 (1): 15-23.

13. Salzman RA, Fujita T, Zhu-Salzman K, Hasegawa PM \& Bressan RA (1999).An improved RNA isolation method for plant tissues containing high levels of phenolic compounds or carbohydrates. Plant Mol. Biol. Rep., 17:11-17.

14. Hu CG, Honda C, Kita M, Zhang Z, Tsuda T \& Moriguchi T(2002). A simple protocol for RNA isolation from fruit trees containing high levels of polysaccharides and polyphenol compounds. Plant Mol. Biol. Rep., 20: 69a-69g.

15. Pateraki I \& Kanellis AK (2004). Isolation of high-quality nucleic acids from Cistus creticus ssp creticus and other medicinal plants. Anal. Biochem., 328: 9092.

16. Jones CS, Ianneta PPM, Woodhead M, Davies HV, McNicol RJ \& Taylor MA (1997). The isolation of RNA from raspberry (Rubus idaeus) fruit. Mol. Biotechnol., 8: 219-221.

17. Jaakola L, Pirttila AM, Halonen M \& Hohtola A (2001). Isolation of high quality RNA from Bilberry (Vaccinium myrtillus L.) fruit.Mol. Biotechnol. 19: 201-203. 
18. Schneiderbauer A, Sandermann H, \& Ernst D(1991). Isolation of functional RNA from plant tissues rich in phenolic compounds.Anal. Biochem., 197: 91-95.

19. Gehrig $\mathrm{HH}$, Winter $\mathrm{K}$, Cushman $\mathrm{J}$, Borland A \& Taybi T(2000).An improved RNA isolation method for succulent plant species rich in polyphenols and polysaccharides. Plant Mol. Biol. Rep., 18: 369-376.

20. Azevedo H, Lino-Neto T \& Tavares RM (2003). An improved method for high quality RNA isolation from needles of adult maritime pine trees. Plant Mol. Biol. Rep., 21:333-338.

21. Dong JZ \& Dunstan DI (1996). A reliable method for extraction of RNA from various conifer tissues. Plant Cell Rep., 15:516-521.

22. Chomczynski P \& Sacchi N (1987). Single step method of RNA isolation by acid guanidinium thiocyanate-phenol-chloroform extraction. Anal Biochem., 162:156-159.

23. Wan CY\& Wilkins TA (1994). A modified hot borate method significantly enhances the yield of high-quality RNA from cotton (Gossypium hirsutum L.). Anal Biochem., 223:7-12.

24. Schneiderbauer A, Sandermann H \& Jr, Ernst D (1991). Isolation of functional RNA from plant tissues rich in phenolic compounds. Anal Biochem., 197:91-95.

25. Asif MH, Dhawan P \& Nath P (2000). A simple procedure for the isolation of high quality RNA from ripening banana fruit. Plant Mol Biol Rep., 18:109-115.

26. Manickavelu A, Kambara K, Mishina K \& Koba T (2007). An efficient method for purifying high quality RNA from wheat pistils. Colloids Surf B 54:254-258.

27. Sambrook J, Frisch FF \& Maniatis $\mathrm{T}$ (1989). Molecular Cloning: A Laboratory Manual, 2nd ed.; Cold Spring Harbor Laboratory Press: Plainview, NY.

28. Chun GH, Chikako H, Masayuki K, Zilian Z, Tomomi T \& Takaya M (2002). A Simple Protocol for RNA Isolation from Fruit Trees Containing High Levels of Polysaccharides and Polyphenol Compounds. Plant Molecular Biology Reporter 20: 69a-69g.

29. Evi K, Werner H \& Dieter E (2000). A simple and efficient protocol for isolation of functional RNA from plant tissues rich in secondary metabolites. Plant Molecular Biology Reporter18, (1) 33-39.

30.Lee M, Beatriz F, Susana G, Ricardo B, Veronica C, Reinaldo C, Mauricio G, Ariel O, Julio R \& Herman S (2005). A Rapid and Efficient Method for Purifying High Quality Total RNA from Peaches (Prunus persica) for Functional Genomics Analyses Biol Res., 38: 83-88.

31. Chang S, Puryear J \& Cairney J (1993). A simple method for isolating RNA from pine trees. Plant Mol Biol Rep., 11: 113-116. 32. Salzman RA, Fujita T, Zhu-Salzman K, Hasegawa PM \& Bressan RA (1999). An improved RNA isolation method for plant tissues containing high levels of phenolic compounds or carbohydrates. Plant Mol Biol Rep., 17: 11-17.

33. Zeng $\mathrm{Y} \&$ Yang $\mathrm{T}$ (2002). RNA isolation from highly viscous samples rich in polyphenols and polysaccharides. Plant $\mathrm{Mol}$ Biol Rep., 20: 417a-417e. 